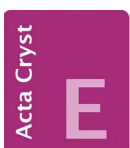

CRYSTALLOGRAPHIC COMMUNICATIONS

ISSN 2056-9890

Received 21 August 2018

Accepted 1 October 2018

Edited by L. Fabian, University of East Anglia, England

Keywords: crystal structure; synthetic metals; tetrathiafuvalenium radical salt; tetrathiafuvalenium polyiodides.

CCDC reference: 1871276

Supporting information: this article has supporting information at journals.iucr.org/e

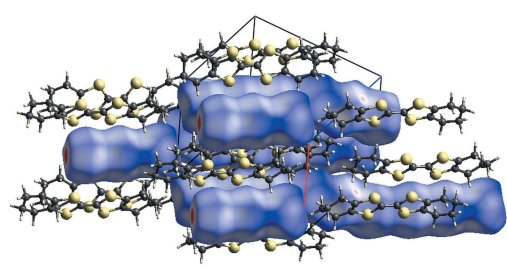

OPEN $\odot$ ACCESS

\section{Synthesis, crystal structure and Hirshfeld analysis of a new crystalline modification of the radical ion salt octamethylenetetrathiafulvalenium triiodide (OMTTF) I 3}

\author{
Adriano Bof de Oliveira, ${ }^{a} *$ Johannes Beck ${ }^{b}$ and Jörg Daniels ${ }^{b}$
}

${ }^{a}$ Departamento de Química, Universidade Federal de Sergipe, Av. Marechal Rondon s/n, 49100-000 São Cristóvão-SE, Brazil, and ${ }^{\mathbf{b}}$ Institut für Anorganische Chemie, Rheinische Friedrich-Wilhelms-Universität Bonn, Gerhard-Domagk-Strasse 1, D-53121 Bonn, Germany. *Correspondence e-mail: adriano@daad-alumni.de

The reaction between 4,5,6,7-tetrahydro-2-(4,5,6,7-tetrahydro-1,3-benzodithiol-

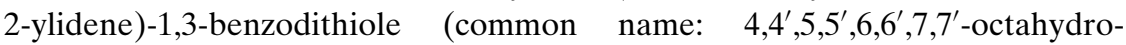
dibenzotetrathiafulvalene, OMTTF) and an excess of iodine in tetrahydrofuran (THF) yielded the respective radical organic polyiodide salt, $\mathrm{C}_{14} \mathrm{H}_{16} \mathrm{~S}_{4}^{+} \cdot \mathrm{I}_{3}{ }^{-}$. The asymmetric unit contains one and a half formula unit of both the cation and the anion, with the half-ions completed through inversion symmetry. The $\left(\mathrm{OMTTF}^{\bullet+}\right)$ positive charge can be assigned by the bond distances and the planar structure of the $\mathrm{C}_{2} \mathrm{~S}_{2} \mathrm{C}=\mathrm{CS}_{2} \mathrm{C}_{2}$ central fragment. In the crystal, trimers of triiodide anions are connected through secondary intermolecular I $\cdots$ I interactions into almost linear $\mathrm{I}_{9}{ }^{3-}$ polyanions. The non-centrosymmetric OMTTF radical cations are linked by $\mathrm{S} \cdots \mathrm{S}$ interactions into centrosymmetric dimers, while the centrosymmetric OMTTF cations remain as discrete units. The $\left(\mathrm{OMTTF}^{\bullet+}\right)$ radical cations and the triiodide anions are linked by weak $\mathrm{C}-$ $\mathrm{H} \cdots \mathrm{I}$ and $\mathrm{C}-\mathrm{H} \cdots \mathrm{S}$ interactions into a three-dimensional network. This work reports the fourth crystalline modification of the $\mathrm{C}_{14} \mathrm{H}_{16} \mathrm{~S}_{4}{ }^{\cdot+} \cdot \mathrm{I}_{3}{ }^{-}$salt. The three previous modifications were obtained from a mixture of acetonitrile and toluene [Konarev et al. (2005). Synth. Met. 151, 231-238].

\section{Chemical context}

Tetrathiafulvalenes (TTF) belong to one of the most important and promising classes of sulfur-containing compounds in materials chemistry, with an emphasis on their electrical conductivity and magnetic properties. As far as we know, the first report about a sulfur-containing heterocycle with the $\mathrm{C}_{2} \mathrm{~S}_{2} \mathrm{C}=\mathrm{CS}_{2} \mathrm{C}_{2}$ central fragment, dibenzotetrathiafulvalene, can be traced back to the early twentieth century (Hurtley \& Smiles, 1926). In the 1970 's and 1980 's, the focus of TTF research changed rapidly from heterocyclic synthetic chemistry to materials chemistry as a result of the wide range of applications in electric and magnetic devices (Fanghänel et al., 1983; Hünig et al., 1973a,b; Richter et al., 1984; Schukat \& Fanghänel, 1979, 1982; Schukat et al., 1979, 1976, 1981, $1982 a, b)$. TTF and its derivatives can be synthesized and manipulated as common organic substances, but they can show properties normally associated with metals or semimetals. The tetrathiafulvalene-tetracyanoquinodimethane compound $\left(\mathrm{TTF}^{\bullet \delta+}\right)_{m}\left(\mathrm{TCNQ}^{\bullet \delta}\right)_{n}$ is considered to be the first synthetic metal because of its high electrical and metallic conductivity down to $53 \mathrm{~K}$. At lower temperatures, a Peierls distortion under pair formation occurs, accompanied by 
transition to semiconducting behaviour (Wudl et al., 1970). A further breakthrough within the field of TTF chemistry came with the synthesis of bis(ethylendithio)tetrathiafulvalene (BEDT-TTF), which opened a completely new area for materials science: superconductivity in molecular systems. $(\mathrm{BEDT}-\mathrm{TTF})_{2}\left(\mathrm{I}_{3}\right)$ is an example of a polyiodide superconductor radical salt at $7 \mathrm{~K}$. In its crystal structure, the $\left(\right.$ BEDT-TTF $\left.^{\bullet+}\right)$ units are stacked along the [110] direction with short intermolecular C...C contacts. Short inter-stack S...S interactions along [100] complete the organic substructure, a layer parallel to (001). As a result of the partially positive charge over the columns of $\left(\mathrm{BEDT}^{\left.-\mathrm{TTF}^{\bullet}{ }^{\circ+}\right)}\right.$ ) and the short contacts, electrical conductivity is directed along this axis. The $\mathrm{I}_{3}{ }^{-}$units form the inorganic subcell, layers parallel to (001), which enables the crystal packing and ensures electrostactic neutrality (Madsen et al., 1999).

A key point within TTF chemistry is the oxidation of the related sulfur-containing molecule to a radical cation with integral or partial charge. The fully oxidized TTF derivatives show salt structures and structure-correlated magnetic properties, while partially oxidized ones show charge-transfer-like behaviour. The radical electron and the positive charge are mainly located over the central fragment of the molecule, the $\mathrm{C}_{2} \mathrm{~S}_{2} \mathrm{C}=\mathrm{CS}_{2} \mathrm{C}_{2}$ unit, being stabilized by the delocalization of electron density from the sulfur atoms to the central $\mathrm{C}^{\bullet}-{ }^{+} \mathrm{C}$ fragment and by the two five-membered rings, which become aromatic in the course of the oxidation. In addition, the electron-density delocalization increases the symmetry of the central unit, from $C_{2 \mathrm{v}}$ to $D_{2 \mathrm{~h}}$, which contributes to the cation stability. A huge number of different anions can be used with TTF-derivative cations, from simple halide ions to coordination compounds, resulting in a great diversity of molecular arrangements, supramolecular structures and physicochemical properties (Saito \& Yoshida, 2007). TTF and its derivatives can also be chemically oxidized with metal salts. For example, the reaction of OMTTF with an excess of $\mathrm{CuBr}_{2}$ yields the salt $\left(\mathrm{OMTTF}^{2+}\right)_{2}\left[\mathrm{Cu}_{2}^{\mathrm{I}} \mathrm{Cu}_{2}{ }_{2} \mathrm{Br}_{10}{ }^{4-}\right]$ (Beck \& Oliveira, 2009). Here the central $\mathrm{C}^{+}-{ }^{+} \mathrm{C} 2$ fragment loses two electrons and the resulting $\mathrm{C}-\mathrm{C}$ bond length is 1.449 (12) $\AA$, a value similar to single bond lengths. Accordingly, rotation between the rings connected by the two central carbon atoms becomes possible

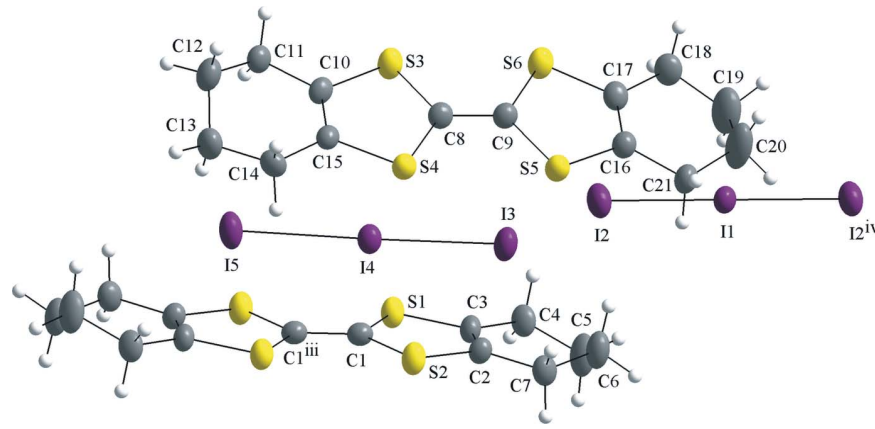

Figure 1

The molecular structure of the title compound, $\delta$-(OMTTF) $\mathrm{I}_{3}$, showing the atom labelling and displacement ellipsoids drawn at the $40 \%$ probability level. Symmetry codes: (iii) $-x+1,-y+1,-z$; (iv) $-x+2$, $-y,-z+1$. and the angle between the mean planes of the two fivemembered rings is $15.34^{\circ}$.

Another key consideration in TTF chemistry is the magnetic properties of the compounds. $\left(\mathrm{TTF}^{\bullet+}\right.$ ) radical derivatives are paramagnetic because of the unpaired electron. Neutral TTF and dicationic $\left(\mathrm{TTF}^{2+}\right)$ derivatives are diamagnetic and a paramagnetic susceptibility will be only possible with the use of paramagnetic anions. For the $\left(\mathrm{OMTTF}^{2+}\right)_{2}\left[\mathrm{Cu}_{2}^{\mathrm{I}} \mathrm{Cu}_{2}{ }_{2} \mathrm{Br}_{10}{ }^{4-}\right]$ salt compound, the anion shows an interesting structure formed by four metal centers with mixed oxidation states and connected tetrahedral coordination polyhedra, building a unique anionic complex showing antiferromagnetic coupling between the $\mathrm{Cu}^{\mathrm{II}}$ centres (Beck \& Oliveira, 2009).<smiles>[AlH2]CCC1=C2SC(=C3SC4=C(CCCC4)S3)[SH]2CC1</smiles>

As part of our research on TTF organic radical chemistry, we report herein the synthesis, crystal structure and Hirshfeld analysis of a new crystalline modification of the octamethylentetrathiafulvalenium triiodide $\left(\mathrm{OMTTF}^{\bullet+}\right)\left(\mathrm{I}_{3}{ }^{-}\right)$compound. Three crystalline modifications of this TTF derivative salt structure have already been reported (Konarev et al., 2005).

\section{Structural commentary}

There are one and a half molecules of both the cation and the anion in the asymmetric unit (Fig. 1) of octamethylentetrathiafulvalenium triiodide $\left(\mathrm{OMTTF}^{\bullet+}\right)\left(\mathrm{I}_{3}{ }^{-}\right),\left(\mathrm{C}_{14} \mathrm{H}_{16} \mathrm{~S}_{4}\right) \mathrm{I}_{3}$, both half-ions being completed by inversion symmetry. The two OMTTF units are fully oxidized to the +1 charge and the electron density is delocalized over the $\mathrm{C}_{2} \mathrm{~S}_{2} \mathrm{C}^{\bullet}-{ }^{+} \mathrm{CS}_{2} \mathrm{C}_{2}$ fragment, as implied by their intermediate bond lengths. The central $\mathrm{C}-\mathrm{C}$ distance is consistent with increased single-bond character due to the loss of one electron. For neutral OMTTF, the central C-C bond length is 1.326 (4) $\AA$ (Zaman et al., 1999), while in this work the values are 1.405 (7) $\AA$ for $\mathrm{C} 1-$ $\mathrm{C}^{\text {iii }}$ [symmetry code: (iii) $-x+1,-y+1,-z$ ] and 1.383 (5) $\AA$ for $\mathrm{C} 8-\mathrm{C} 9$. At the same time, the $\mathrm{S}-\mathrm{C}$ bond distances are consistent with increased double-bond character, since the sulfur atoms polarize the electron density to the central $\mathrm{C}-\mathrm{C}$ bond to stabilize the positive charge and the two fivemembered rings become aromatic. For neutral OMTTF, the $\mathrm{S}-\mathrm{C}$ bond distance is 1.759 (3) $\AA$. For the $\left(\mathrm{OMTTF}^{\bullet+}\right)$ molecule in this work, the $\mathrm{S}-\mathrm{C}$ bond distances are $\mathrm{S} 1-\mathrm{C} 1=$ 1.719 (3), $\mathrm{S} 2-\mathrm{C} 1=1.715$ (4), $\mathrm{S} 3-\mathrm{C} 8=1.711$ (4), $\mathrm{S} 4-\mathrm{C} 8=$ 1.720 (4), S5-C9 $=1.727$ (4) and S6-C9 = 1.724 (4) $\AA$. This change in the bond character is a key feature in distinguishing between neutral and cationic TTF derivatives and is well known in the literature (Zaman et al., 1999). The non-planarity of the six-membered rings is shown by the maximum deviation from the mean plane of the non- $\mathrm{H}$ atoms for the $\left(\mathrm{OMTTF}^{\bullet+}\right)$ molecules, 0.307 (4) $\AA$ for C5 and 0.415 (4) $\AA$ for C13. The central fragments of the molecules are nearly planar, with a 


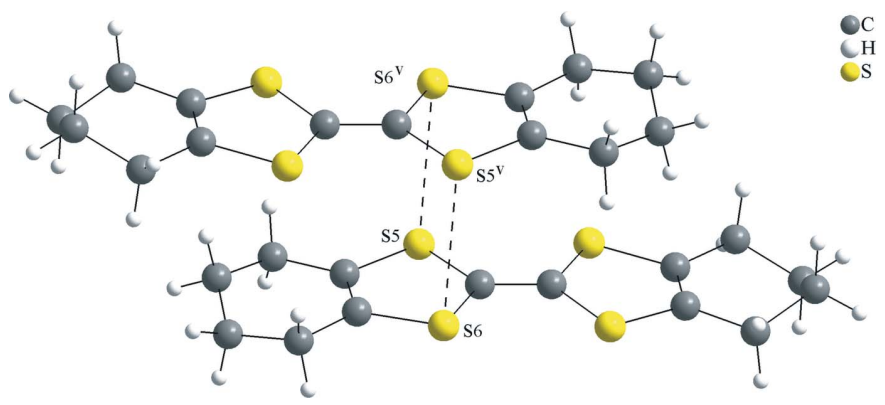

Figure 2

Representation of the centrosymmetric dimer $\left(\mathrm{OMTTF}^{\bullet+}\right)_{2}{ }^{2+}$ of the title compound. The S...S intermolecular interactions are drawn as dashed lines. Symmetry code: $(\mathrm{v})-x+1,-y+1,-z+1$.

maximum deviation from the mean plane of the non- $\mathrm{H}$ atoms of the C8-C10/C15-C17/S3-S6 fragment of 0.0790 (18) $\AA$ for $\mathrm{S} 6$ and a maximum deviation from the $\mathrm{C} 1-\mathrm{C} 3 / \mathrm{S} 1 / \mathrm{S} 2 / \mathrm{C}^{\mathrm{iii}}-\mathrm{C} 3^{\mathrm{iii}} /$ $\mathrm{S}^{\mathrm{iii}} / \mathrm{S} 22^{\mathrm{iii}}$ fragment of 0.0221 (11) $⿱$ for S2. The r.m.s deviations of their atoms from these mean planes are 0.0504 and $0.016 \AA$, respectively. In the triiodide anion I2-I1-I $2^{\text {iv }}$ [symmetry code: (iv) $-x+2,-y,-z+1]$, the two $\mathrm{I}-\mathrm{I}$ bonds are identical; in the second anion I3-I4-I5, the two I-I bonds differ only by $0.06 \AA$. Thus, polarization of the anions by the cations can be regarded as negligible (Fig. 1).

\section{Supramolecular features}

$\left(\mathrm{OMTTF}^{\bullet+}\right)\left(\mathrm{I}_{3}{ }^{-}\right)$is an organic radical compound with a salt structure. The cations and anions alternate in the crystal structure and no $\pi-\pi$ stacking, organic radical columns or an
Table 1

Hydrogen-bond geometry $\left(\AA,{ }^{\circ}\right)$.

\begin{tabular}{lllll}
\hline$D-\mathrm{H} \cdots A$ & $D-\mathrm{H}$ & $\mathrm{H} \cdots A$ & $D \cdots A$ & $D-\mathrm{H} \cdots A$ \\
\hline $\mathrm{C} 18-\mathrm{H} 23 \cdots \mathrm{S} 3^{\mathrm{i}}$ & 0.97 & 2.80 & $3.669(4)$ & 150 \\
$\mathrm{C} 21-\mathrm{H} 17 \cdots \mathrm{I} 1^{\mathrm{ii}}$ & 0.97 & 3.06 & $3.763(4)$ & 131 \\
\hline
\end{tabular}

Symmetry codes: (i) $-x+2,-y+1,-z+1$; (ii) $x-1, y, z$.

organic conductor subcell is observed, as e.g. for the (BEDT$\left.\mathrm{TTF}^{\circ}{ }^{\delta+}\right)_{m}\left(\mathrm{I}_{3}{ }^{-}\right)_{n}$ superconductor (Madsen et al., 1999). In the crystal structure of the title compound, pairs of non-centrosymmetric $\left(\mathrm{OMTTF}^{\bullet+}\right)$ units are connected through $\mathrm{S} \cdots \mathrm{S}$ intermolecular interactions into inversion dimers. The sum of the van der Waals radii for S...S contacts is $3.6 \AA$ (Bondi, 1964; Rowland \& Taylor, 1996) and the distance for the S5 $\cdots \mathrm{S}^{\mathrm{v}}{ }^{\mathrm{interaction}}$ amounts to $3.4841(16) \AA$ (Fig. 2) [symmetry code: (v) $-x+1,-y+1,-z+1$ ]. Meanwhile, the centrosymmetric OMTTF cations remain as discrete units, with no short intermolecular contacts. The triiodide anions show a close intermolecular I - . I d distance of 3.5934 (5) $\AA$, much shorter than the sum of the van der Waals radii, $3.96 \AA$ (Bondi, 1964; Rowland \& Taylor, 1996), and forming an almost linear polyiodide anion $\mathrm{I}_{9}{ }^{3-}$ aligned with the [021] direction. Finally, the $\left(\mathrm{OMTTF}^{\bullet+}\right)$ entities and the $\mathrm{I}_{3}{ }^{-}$anions are linked to each other by $\mathrm{C}-\mathrm{H} \cdots \mathrm{I}$ and $\mathrm{C}-\mathrm{H} \cdots \mathrm{S}$ hydrogen bonds, forming a three-dimensional network (Fig. 3 and Table 1). Additionally, there are very weak intermolecular contacts with $\mathrm{H}$...I distances from 3.21 to $3.38 \AA$ and with a $\mathrm{H}$...S distance of $3.00 \AA$, which are longer the sum of the van der Waals radii for the respective atoms but are relevant for the crystal cohesion (Fig. 3 and Hirshfeld analysis section).

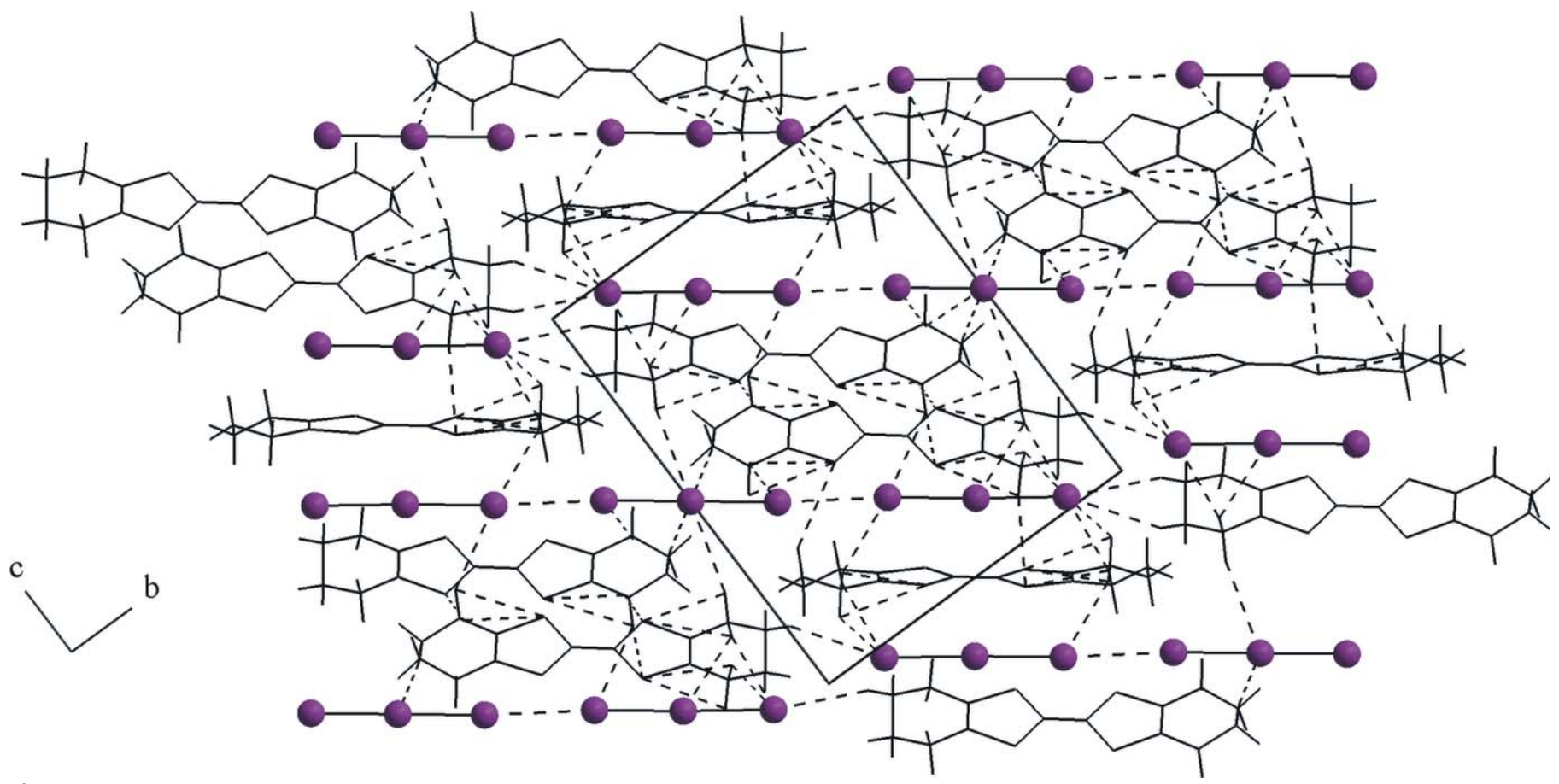

Figure 3

Section of the crystal structure of the title compound, $\delta$-(OMTTF) $\mathrm{I}_{3}$, showing the three-dimensional hydrogen-bonded network built up by $\mathrm{H} \cdots \mathrm{I}$ intermolecular interactions (shown as dashed lines). The $\mathrm{I}_{3}{ }^{-}$units are linked by $\mathrm{I} \cdots \mathrm{I}$ intermolecular interactions, also drawn as dashed lines, forming one-dimensional chains of nine I atoms. The figure is simplified for clarity. 


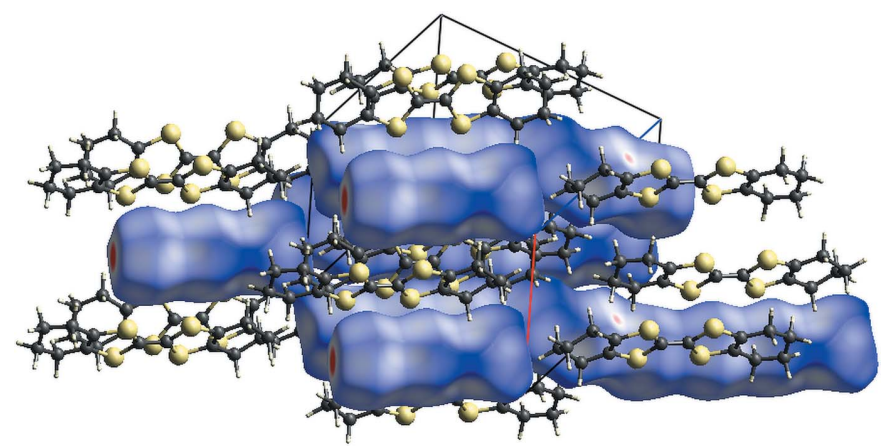

Figure 4

Section of the crystal structure of the title compound, $\delta$-(OMTTF) $\mathrm{I}_{3}$. The Hirshfeld surface representation $\left(d_{\text {norm }}\right)$ is drawn for the I atoms, while the $\left(\mathrm{OMTTF}^{\bullet+}\right)$ entities are drawn using a 'ball-and-stick' model for clarity. The surface regions with strongest intermolecular interactions are shown in magenta, the $\left(\mathrm{I}_{3}{ }^{-}\right) \cdots\left(\mathrm{I}_{3}{ }^{-}\right)$interactions for example. The surface regions with weak interactions, e.g. the $\mathrm{H}$...I contacts, are pale magenta in colour. The strongest and the frequently observed intermolecular interactions (in \%) are not necessarily are the same. The $a$ axis is drawn in red and the $c$ axis is drawn in blue.

\section{Hirshfeld surface analysis}

The Hirshfeld surface graphical representation (Hirshfeld, 1977) of the polyiodide oligomers in a section of the crystal structure indicates, in magenta, the locations of the I $\cdots \mathrm{I}$ intermolecular contacts, while the $\left(\mathrm{OMTTF}^{\bullet+}\right)$ units are represented using a 'ball-and-stick' model for clarity (Fig. 4). The $\left(\mathrm{I}_{3}{ }^{-}\right) \cdots\left(\mathrm{I}_{3}{ }^{-}\right)$contacts are the most striking features in the Hirshfeld surface figure, but the most important contribution to the crystal cohesion (in \%) comes from the $\mathrm{H} \cdots \mathrm{H}$ and $\mathrm{H} \cdots \mathrm{I}$ intermolecular interactions, amounting to 31.40 and $34.60 \%$ of the surface contacts, respectively. The selected contributions to the crystal packing are shown as twodimensional Hirshfeld surface fingerprint plots with cyan dots (Wolff et al., 2012). The $d_{\mathrm{e}}\left(y\right.$ axis) and $d_{\mathrm{i}}(x$ axis) values are the distances to the closest external and internal atoms (values in $\AA$ ) from a given point on the Hirshfeld surface (Fig. $5 a$ for $\mathrm{H} \cdots \mathrm{H}$ and $5 b$ for $\mathrm{H} \cdots \mathrm{I})$.
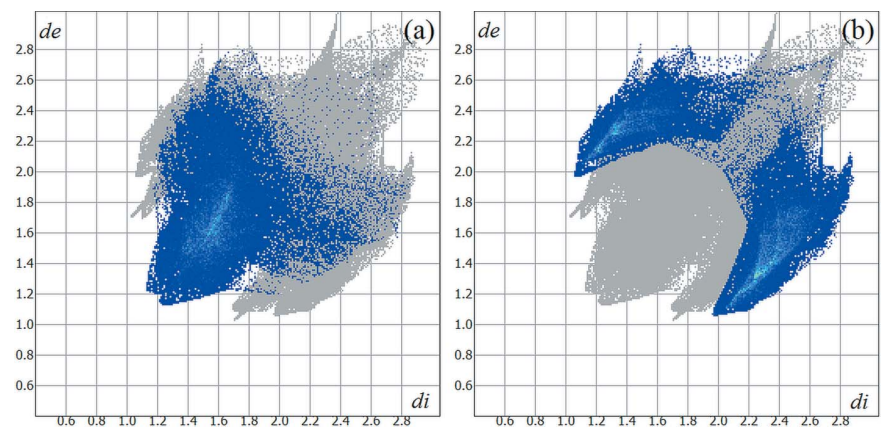

Figure 5

Hirshfeld surface fingerprint plot for the title compound showing $(a)$ the $\mathrm{H} \cdots \mathrm{H}$ and $(b)$ the $\mathrm{H} \cdots \mathrm{I}$ contacts in detail (cyan dots). The contribution of the these intermolecular interactions to the crystal packing amounts to 31.40 and $34.60 \%$, respectively.

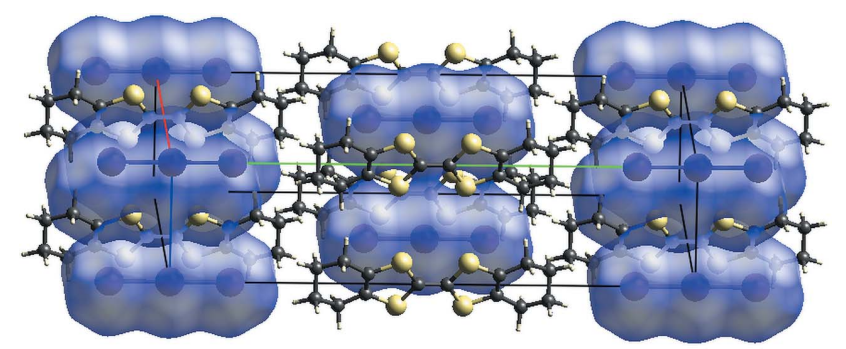

(a)

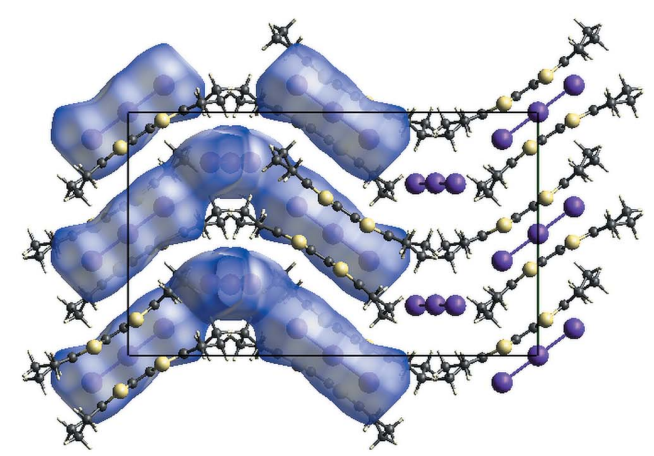

(b)

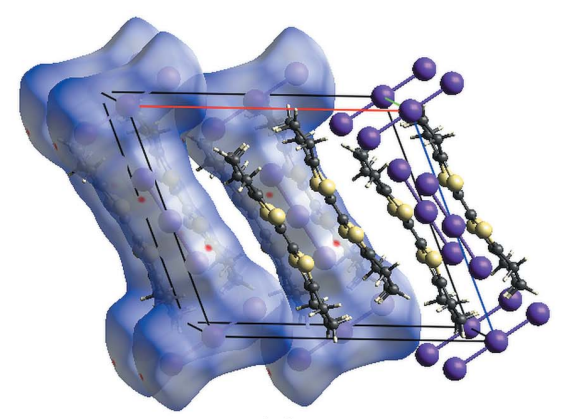

(c)

Figure 6

Sections of the crystal structures of the $(a) \alpha,(b) \beta$ and (c) $\gamma$ polymorphs of $\left(\mathrm{OMTTF}^{\bullet+}\right)\left(\mathrm{I}_{3}{ }^{-}\right)$. For details about the structures, please see: the Database survey section of this work and Konarev et al. (2005). For clarity, the $\mathrm{I}_{3}{ }^{-}$units are drawn in different formats: either as Hirshfeld surface representations $\left(d_{\text {norm }}\right)$ or using 'ball-and-stick' models. The $a$ axis is drawn in red, the $b$ axis is drawn in green and the $c$ axis in blue. The cell in (b) is viewed along the $a$ axis.

\section{Database survey}

To the best of our knowledge and using database tools such as SciFinder (Chemical Abstracts Service, 2018), three different crystalline polymorphs of $\left(\mathrm{OMTTF}^{{ }^{+}}\right)\left(\mathrm{I}_{3}{ }^{-}\right)$have been reported (Konarev et al., 2005), now designated as $\alpha$ [monoclinic, $C 2 / m, a=7.7696(8), b=25.2965(15)$ and $c=$ 5.7335 (6) $\AA$ ],$\beta$ [orthorhombic, $C 222_{1}, a=7.7696$ (8), $b=$ 25.2965 (15) and $c=5.7335$ (6)] and $\gamma$ [also monoclinic, $C 2 / \mathrm{m}$, $a=16.670$ (1), $b=9.182$ (1) and $c=14.426$ (1) §] (Fig. $6 a$ for the $\alpha$-, Fig. $6 b$ for the $\beta$ and Fig. $6 c$ for the $\gamma$ form). All three crystalline modifications are obtained by the same synthetic route and from a mixture of acetonitrile and toluene as crystallization solvent. All three polymorphs show a salt structure, and the new $\delta$ polymorph fits into the series. There are, however, distinct differences in the interactions between the 

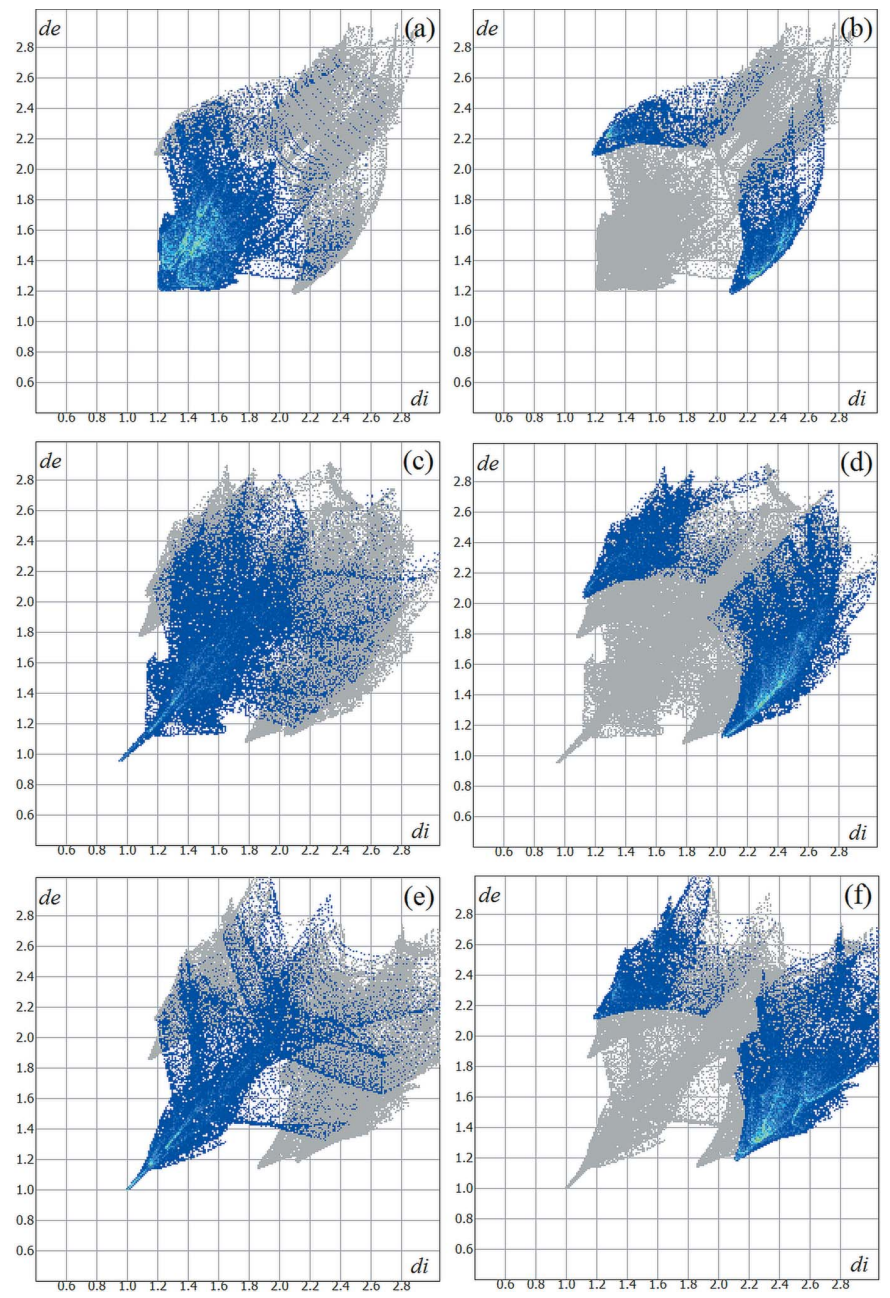

Figure 7

Two-dimensional Hirshfeld surface fingerprint plots for the $\alpha, \beta$ and $\gamma$ $\left(\mathrm{OMTTF}^{\bullet+}\right)\left(\mathrm{I}_{3}{ }^{-}\right)$crystalline modifications. The $\mathrm{H} \cdots \mathrm{H}$ and $\mathrm{H} \cdots \mathrm{I}$ intermolecular contacts are drawn as cyan dots. The contributions of these interactions for the crystal packing of the $\alpha$ form amount to $(a) 43.30 \%$ and $(b) 17.40 \%$, respectively. For the $\beta$ form the values amount to $(c)$ $29.20 \%$ and $(d) 33.90 \%$ and, finally, for the $\gamma$ form the values are $(e)$ $23.00 \%$ and $(f) 39.70 \%$.

radical cations in the respective structures. In the $\beta$ (Fig. $6 b$ ) and the $\gamma$ (Fig. $6 c$ ) modifications, the OMTTF radical ions form $\pi$ dimers $\left(\mathrm{OMTTF}^{\bullet+}\right)_{2}{ }^{2+}$. The molecules are arranged in a parallel fashion. Two four-center two-electron bonds between the $\mathrm{S}$ atoms are present with typical S...S distances around $3.3 \AA$. The intermolecular bonds between the central parts of the two molecules cause steric repulsion in the peripheral parts. As a consequence, the molecules are no longer planar but achieve a typical bent shape. For the $\delta$ modification, a centrosymmetric dimer $\left(\mathrm{OMTTF}^{\bullet+}\right)_{2}{ }^{2+}$ is observed for the radical cations without a molecular inversion centre. Unlike in the $\beta$ and $\gamma$ forms, in the $\delta$ form the $\left(\mathrm{OMTTF}^{\bullet+}\right)$ units of the dimer are not face-to-face, but offset (Fig. 2).

In the $\alpha$ and the $\delta$ forms, concerning the centrosymmetric radical cations only, the $\left(\mathrm{OMTTF}^{\bullet+}\right)$ units are mainly isolated from each other. Only weak intermolecular interactions with
S...S distances longer than the sum of the van der Waals radii of two sulfur atoms are observed. This is in line with the almost undistorted planarity of the entire molecule. For the three modifications, some $\mathrm{I}_{3}{ }^{-}$units were drawn as Hirshfeld surfaces (Hirshfeld, 1977) and some others as 'ball-and-stick' models for clarity. The selected contributions to the crystal packing are shown as two-dimensional Hirshfeld surface fingerprint plots with cyan dots (Wolff et al., 2012). The analysis of the complete asymmetric units of the three crystalline modifications suggests that the contribution of the $\mathrm{H} \cdots \mathrm{H}$ and $\mathrm{H} \cdots \mathrm{I}$ contacts for the crystal cohesion are $43.30 \%$ and $17.40 \%$ for the $\alpha$ modification (Fig. $7 a$ and $7 b$ ). For the $\beta$ modification, the values for the $\mathrm{H} \cdots \mathrm{H}$ and $\mathrm{H} \cdots \mathrm{I}$ contacts amount to $29.20 \%$ and $33.90 \%$ (Fig. $7 c$ and $7 d$ ). Finally, for the $\gamma$ modification the values for the selected contacts amount to $23.00 \%$ and $39.70 \%$ (Fig. $7 e$ and $7 f$ ). The $\mathrm{H} \cdots \mathrm{H}$ and $\mathrm{H} \cdots \mathrm{I}$ contacts were selected for comparison and analysis of the four crystalline modifications because they are the most frequent (in percentage terms) for all structures, but still show clear differences between the polymorphs.

\section{Synthesis and crystallization}

All starting materials are commercially available and were used without further purification. In order to obtain fully oxidized TTF radical cations, an excess of $\mathrm{I}_{2}$ was employed. In a typical experiment, OMTTF $\left(3.00 \times 10^{-4} \mathrm{~mol}\right)$ and iodine $\left(1.20 \times 10^{-3} \mathrm{~mol}\right)$ were separately dissolved in anhydrous tetrahydrofurane $(40 \mathrm{~mL})$. The solutions were added separately and simultaneously to each tubing of a U-shaped Schlenk flask previously evacuated and filled with argon. As the U shape was divided into two compartments by a level 3 porosity frit, the diffusion of the two solutions was slow. After some weeks, black crystals suitable for X-ray diffraction were obtained. The OMTTF radical cation triiodide is air-sensitive in solution, but stable for years in the solid state.

\section{Refinement}

Crystal data, data collection and structure refinement details are summarized in Table 2. Hydrogen atoms were positioned with idealized geometry and refined isotropically using a riding model, with $U_{\text {iso }}(\mathrm{H})=1.2 U_{\text {eq }}(\mathrm{C})$, and with $\mathrm{C}-\mathrm{H}=$ $0.97 \AA$. The possibility of disorder was verified with a new refinement, but rejected. Although the shapes of the displacement ellipsoid for C20, C21 and C5 are different from those of nearby atoms, these peripheral $s p^{3}$ atoms have more freedom to move and no clear splitting was suggested by the data.

\section{Acknowledgements}

We gratefully acknowledge financial support by the State of North Rhine-Westphalia, Germany. ABO is a former DAAD scholarship holder and alumnus of the University of Bonn, Germany, and thanks both of the institutions for the long-time support. 
Table 2

Experimental details.

\begin{tabular}{ll}
\hline Crystal data & \\
Chemical formula & $\mathrm{C}_{14} \mathrm{H}_{16} \mathrm{~S}_{4}{ }^{+} \cdot \mathrm{I}_{3}{ }^{-}$ \\
$M_{\mathrm{r}}$ & 693.21 \\
Crystal system, space group & Triclinic, $P \overline{1}$ \\
Temperature $(\mathrm{K})$ & 293 \\
$a, b, c(\AA)$ & $8.4334(1), 12.1857(2), 14.9874(3)$ \\
$\alpha, \beta, \gamma\left({ }^{\circ}\right)$ & $90.063(1), 94.279(1), 104.063(1)$ \\
$V\left(\AA^{3}\right)$ & $1489.59(4)$ \\
$Z$ & 3 \\
Radiation type & Mo $K \alpha$ \\
$\mu\left(\mathrm{mm}^{-1}\right)$ & 5.13 \\
Crystal size (mm) & $0.21 \times 0.20 \times 0.03$ \\
& \\
Data collection & Nonius KappaCCD \\
Diffractometer & Analytical $($ Alcock, 1970) \\
Absorption correction & $0.375,0.859$ \\
$T_{\text {min }}, T_{\text {max }}$ & $30936,6630,4525$ \\
No. of measured, independent and & \\
$\quad$ observed $[I>2 \sigma(I)]$ reflections & 0.064 \\
$R_{\text {int }}$ & 0.651 \\
$(\text { sin } \theta / \lambda)_{\text {max }}\left(\AA^{-1}\right)$ & \\
Refinement & \\
$R\left[F^{2}>2 \sigma\left(F^{2}\right)\right], w R\left(F^{2}\right), S$ & $0.031,0.066,1.01$ \\
No. of reflections & 6630 \\
No. of parameters & 287 \\
H-atom treatment & $\mathrm{H}$-atom parameters constrained \\
$\Delta \rho_{\text {max }}, \Delta \rho_{\text {min }}\left(\mathrm{e} \AA^{-3}\right)$ & $0.60,-0.58$ \\
\hline
\end{tabular}

Computer programs: COLLECT (Nonius, 1998), HKL, DENZO and SCALEPACK (Otwinowski \& Minor, 1997), SHELXT2014 (Sheldrick, 2015a), SHELXL2016 (Sheldrick, 2015b), WinGX (Farrugia, 2012), DIAMOND (Brandenburg, 2006), publCIF (Westrip, 2010) and enCIFer (Allen et al., 2004).

\section{Funding information}

Funding for this research was provided by: DFG (Deutsche Forschungsgemeinschaft), SFB 813 (Sonderforschungsbereich 813): Chemie an Spinzentren: Konzepte, Mechanismen, Funktionen.

\section{References}

Alcock, N. W. (1970). Crystallographic Computing, edited by F. R. Ahmed, S. R. Hall \& C. P. Huber, p. 271. Copenhagen: Munksgaard.

Allen, F. H., Johnson, O., Shields, G. P., Smith, B. R. \& Towler, M. (2004). J. Appl. Cryst. 37, 335-338.
Beck, J. \& Bof de Oliveira, A. (2009). Z. Anorg. Allg. Chem. 635, 445449.

Bondi, A. (1964). J. Phys. Chem. 68, 441-451.

Brandenburg, K. (2006). DIAMOND. Crystal Impact GbR, Bonn, Germany.

Chemical Abstracts Service (2018). RN 58-08-2. Columbus, Ohio, USA (accessed via SciFinder on August 10, 2018).

Fanghänel, E., Schukat, G., Schützendübel, J. \& Humsch, W. (1983). J. Prakt. Chem. 325, 976-980.

Farrugia, L. J. (2012). J. Appl. Cryst. 45, 849-854.

Hirshfeld, H. L. (1977). Theor. Chim. Acta, 44, 129-138.

Hünig, S., Kiesslich, G., Quast, H. \& Scheutzow, D. (1973a). Justus Liebigs Ann. Chem. 765, 310-323.

Hünig, S., Scheutzow, D. \& Schlaf, H. (1973b). Justus Liebigs Ann. Chem. 765, 126-136.

Hurtley, W. R. H. \& Smiles, S. (1926). J. Chem. Soc. 129, 2263-2270.

Konarev, D. V., Khasanov, S. S., Otsuka, A., Saito, G. \& Lyubovskaya, R. N. (2005). Synth. Met. 151, 231-238.

Madsen, D., Burghammer, M., Fiedler, S. \& Müller, H. (1999). Acta Cryst. B55, 601-606.

Nonius (1998). COLLECT. Nonius BV, Delft, The Netherlands.

Otwinowski, Z. \& Minor, W. (1997). Methods in Enzymology, Vol. 276, Macromolecular Crystallography, Part A, edited by C. W. Carter Jr \& R. M. Sweet, pp. 307-326. New York: Academic Press.

Richter, A. M., Schukat, G. \& Fanghänel, E. (1984). Amt für Erfindungs- und Patentwesen der DDR, former German Democratic Republic Patent Office. Patent number: 214846.

Rowland, R. S. \& Taylor, R. (1996). J. Phys. Chem. 100, 7384-7391. Saito, G. \& Yoshida, Y. (2007). Bull. Chem. Soc. Jpn, 80, 1-137.

Schukat, G. \& Fanghänel, E. (1979). J. Prakt. Chem. 321, 675-679.

Schukat, G. \& Fanghänel, E. (1982). J. Prakt. Chem. 324, 1011-1016.

Schukat, G., Fanghänel, E. \& Chyla, A. (1979). Potsdamer Forsch., Reihe B, 20, 99-103.

Schukat, G., Fanghänel, E. \& Chyla, A. (1982a). J. Prakt. Chem. 324, 422-428.

Schukat, G., Mörke, W. \& Fanghänel, E. (1981). Z. Chem. 21, 153-154. Schukat, G., Richter, A. M. \& Fanhänel, E. (1982b). J. Prakt. Chem. 324, 479-484.

Schukat, G., van Hinh, L. \& Fanghänel, E. (1976). Z. Chem. 16, 360361.

Sheldrick, G. M. (2015a). Acta Cryst. A71, 3-8.

Sheldrick, G. M. (2015b). Acta Cryst. C71, 3-8.

Westrip, S. P. (2010). J. Appl. Cryst. 43, 920-925.

Wolff, S. K., Grimwood, D. J., McKinnon, J. J., Turner, M. J., Jayatilaka, D. \& Spackman, M. A. (2012). CrystalExplorer3.1. University of Western Australia, Perth, Australia.

Wudl, F., Smith, G. M. \& Hufnagel, E. J. (1970). J. Chem. Soc. D, pp. 1453-1454.

Zaman, M. B., Toyoda, J., Morita, Y., Nakamura, S., Yamochi, H., Saito, G. \& Nakasuji, K. (1999). Synth. Met. 102, 1691-1692. 


\section{supporting information}

Acta Cryst. (2018). E74, 1547-1552］ [https://doi.org/10.1107/S2056989018013907]

Synthesis, crystal structure and Hirshfeld analysis of a new crystalline modification of the radical ion salt octamethylenetetrathiafulvalenium triiodide (OMTTF) $I_{3}$

\section{Adriano Bof de Oliveira, Johannes Beck and Jörg Daniels}

Computing details

Data collection: COLLECT (Nonius, 1998); cell refinement: HKL and SCALEPACK (Otwinowski \& Minor, 1997); data reduction: HKL, DENZO and SCALEPACK (Otwinowski \& Minor, 1997); program(s) used to solve structure:

SHELXT2014 (Sheldrick, 2015a); program(s) used to refine structure: SHELXL2016 (Sheldrick, 2015b); molecular graphics: WinGX (Farrugia, 2012), DIAMOND (Brandenburg, 2006) and CrystalExplorer (Wolff et al., 2012); software used to prepare material for publication: publCIF (Westrip, 2010) and enCIFer (Allen et al., 2004).

4,5,6,7-Tetrahydro-2-(4,5,6,7-tetrahydro-1,3-benzodithiol-2-ylidene)-1,3-benzodithiole

\section{Crystal data}

$\mathrm{C}_{14} \mathrm{H}_{16} \mathrm{~S}_{4}^{+} \cdot \mathrm{I}_{3}^{-}$

$M_{r}=693.21$

Triclinic, $P \overline{1}$

$a=8.4334(1) \AA$

$b=12.1857$ (2) $\AA$

$c=14.9874(3) \AA$

$\alpha=90.063(1)^{\circ}$

$\beta=94.279(1)^{\circ}$

$\gamma=104.063(1)^{\circ}$

$V=1489.59(4) \AA^{3}$

Data collection

Nonius KappaCCD diffractometer

Radiation source: fine-focus sealed tube, Enraf Nonius FR590

Detector resolution: 9 pixels $\mathrm{mm}^{-1}$

CCD rotation images, thick slices scans

Absorption correction: analytical (Alcock, 1970)

$T_{\min }=0.375, T_{\max }=0.859$

\section{Refinement}

Refinement on $F^{2}$

Least-squares matrix: full

$R\left[F^{2}>2 \sigma\left(F^{2}\right)\right]=0.031$

$w R\left(F^{2}\right)=0.066$
$Z=3$

$F(000)=969$

$D_{\mathrm{x}}=2.318 \mathrm{Mg} \mathrm{m}^{-3}$

Mo $K \alpha$ radiation, $\lambda=0.71073 \AA$

Cell parameters from 6128 reflections

$\theta=2.9-27.5^{\circ}$

$\mu=5.13 \mathrm{~mm}^{-1}$

$T=293 \mathrm{~K}$

Plate, black

$0.21 \times 0.20 \times 0.03 \mathrm{~mm}$

30936 measured reflections

6630 independent reflections

4525 reflections with $I>2 \sigma(I)$

$R_{\text {int }}=0.064$

$\theta_{\text {max }}=27.6^{\circ}, \theta_{\min }=2.9^{\circ}$

$h=-10 \rightarrow 10$

$k=-15 \rightarrow 15$

$l=-19 \rightarrow 19$ 
Primary atom site location: structure-invariant direct methods

Secondary atom site location: difference Fourier map

Hydrogen site location: inferred from neighbouring sites

$\mathrm{H}$-atom parameters constrained

$$
\begin{aligned}
& w=1 /\left[\sigma^{2}\left(F_{\mathrm{o}}^{2}\right)+(0.0266 P)^{2}\right] \\
& \text { where } P=\left(F_{\mathrm{o}}^{2}+2 F_{\mathrm{c}}^{2}\right) / 3 \\
& (\Delta / \sigma)_{\max }=0.001 \\
& \Delta \rho_{\max }=0.60 \mathrm{e} \AA^{-3} \\
& \Delta \rho_{\min }=-0.58 \mathrm{e} \AA^{-3} \\
& \text { Extinction correction: SHELXL2016 } \\
& \quad(\text { Sheldrick, } 2015 \mathrm{~b}), \\
& \quad \mathrm{Fc}^{*}=\mathrm{kFc}\left[1+0.001 \mathrm{xFc}{ }^{2} \lambda^{3} / \sin (2 \theta)\right]^{-1 / 4} \\
& \text { Extinction coefficient: } 0.00314(13)
\end{aligned}
$$

\begin{tabular}{|c|c|c|c|c|}
\hline & $x$ & $y$ & $z$ & $U_{\text {iso }} * / U_{\text {eq }}$ \\
\hline $\mathrm{C} 1$ & 0.4855 & $0.4532(3)$ & $0.0283(2)$ & $0.0362(9)$ \\
\hline $\mathrm{C} 2$ & $0.3544(5)$ & $0.2803(3)$ & $0.1170(2)$ & $0.0376(9)$ \\
\hline $\mathrm{C} 3$ & $0.5172(5)$ & 0.2928 & $0.1320(2)$ & $0.0380(9)$ \\
\hline $\mathrm{C} 4$ & $0.5919(5)$ & $0.2134(3)$ & $0.1886(3)$ & $0.0452(11)$ \\
\hline $\mathrm{H} 7$ & 0.681449 & 0.195920 & 0.158918 & $0.054 *$ \\
\hline $\mathrm{H} 8$ & 0.636151 & 0.249881 & 0.245726 & $0.054^{*}$ \\
\hline $\mathrm{C} 5$ & $0.4663(6)$ & $0.1060(4)$ & $0.2038(3)$ & $0.0699(15)$ \\
\hline H5 & 0.454486 & 0.057149 & 0.151362 & $0.084^{*}$ \\
\hline H6 & 0.507530 & 0.067726 & 0.253869 & $0.084 *$ \\
\hline C6 & $0.3023(5)$ & $0.1197(4)$ & 0.2222 & 0.0639 (13) \\
\hline H3 & 0.310645 & 0.158159 & 0.279685 & $0.077^{*}$ \\
\hline $\mathrm{H} 4$ & 0.229222 & 0.045277 & 0.226698 & $0.077^{*}$ \\
\hline $\mathrm{C} 7$ & $0.2274(5)$ & $0.1851(3)$ & $0.1522(3)$ & 0.0467 (11) \\
\hline H1 & 0.174160 & 0.134295 & 0.103131 & $0.056^{*}$ \\
\hline $\mathrm{H} 2$ & 0.144579 & 0.215407 & 0.178135 & $0.056^{*}$ \\
\hline $\mathrm{S} 1$ & $0.64287(12)$ & $0.40535(9)$ & $0.08132(7)$ & 0.0430 \\
\hline $\mathrm{S} 2$ & $0.29183(12)$ & $0.37907(9)$ & $0.04903(7)$ & $0.0459(3)$ \\
\hline $\mathrm{C} 8$ & $0.6525(4)$ & 0.5857 (3) & $0.3377(2)$ & $0.0363(9)$ \\
\hline C9 & $0.6279(4)$ & $0.4954(3)$ & $0.3950(2)$ & $0.0380(9)$ \\
\hline $\mathrm{C} 10$ & $0.7741(4)$ & $0.7704(3)$ & $0.2585(2)$ & $0.0359(9)$ \\
\hline $\mathrm{C} 11$ & $0.8902(5)$ & $0.8796(3)$ & 0.2380 & $0.0417(10)$ \\
\hline H15 & 0.982120 & 0.864480 & 0.209144 & $0.050 *$ \\
\hline H16 & 0.932298 & 0.921952 & 0.293088 & $0.050 *$ \\
\hline $\mathrm{C} 12$ & $0.8012(6)$ & 0.9493 (4) & $0.1762(3)$ & $0.0591(12)$ \\
\hline H13 & 0.733418 & 0.983985 & 0.211080 & $0.071 *$ \\
\hline H14 & 0.881546 & 1.009379 & 0.150601 & $0.071^{*}$ \\
\hline $\mathrm{C} 13$ & $0.6958(6)$ & 0.8785 (4) & $0.1021(3)$ & $0.0597(13)$ \\
\hline H11 & 0.763997 & 0.844999 & 0.066617 & $0.072 *$ \\
\hline H12 & 0.646144 & 0.926795 & 0.063457 & $0.072 *$ \\
\hline $\mathrm{C} 14$ & $0.5609(5)$ & $0.7848(3)$ & $0.1366(2)$ & $0.0456(10)$ \\
\hline
\end{tabular}

Special details

Geometry. All esds (except the esd in the dihedral angle between two 1.s. planes) are estimated using the full covariance matrix. The cell esds are taken into account individually in the estimation of esds in distances, angles and torsion angles; correlations between esds in cell parameters are only used when they are defined by crystal symmetry. An approximate (isotropic) treatment of cell esds is used for estimating esds involving 1.s. planes.

Fractional atomic coordinates and isotropic or equivalent isotropic displacement parameters $\left(\AA^{2}\right)$ 


\begin{tabular}{|c|c|c|c|c|}
\hline H9 & 0.474640 & 0.816605 & 0.156809 & $0.055^{*}$ \\
\hline H10 & 0.513735 & 0.730336 & 0.088775 & $0.055^{*}$ \\
\hline $\mathrm{C} 15$ & $0.6317(5)$ & 0.7260 & $0.2137(2)$ & $0.0352(9)$ \\
\hline $\mathrm{C} 16$ & $0.5244(5)$ & 0.3034 & 0.4685 & $0.0403(10)$ \\
\hline $\mathrm{C} 17$ & $0.6676(5)$ & 0.3521 & $0.5147(3)$ & $0.0411(10)$ \\
\hline C18 & $0.7419(5)$ & $0.2956(4)$ & 0.5897 & $0.0490(11)$ \\
\hline $\mathrm{H} 23$ & 0.856148 & 0.301230 & 0.580341 & $0.059 *$ \\
\hline $\mathrm{H} 24$ & 0.738052 & 0.334997 & 0.645504 & $0.059 *$ \\
\hline C19 & $0.6560(6)$ & $0.1743(4)$ & $0.5972(4)$ & $0.0866(18)$ \\
\hline $\mathrm{H} 21$ & 0.711564 & 0.129966 & 0.562472 & $0.104^{*}$ \\
\hline $\mathrm{H} 22$ & 0.669841 & 0.153589 & 0.659273 & $0.104^{*}$ \\
\hline $\mathrm{C} 20$ & $0.4869(6)$ & $0.1409(5)$ & $0.5699(4)$ & $0.096(2)$ \\
\hline H19 & 0.427943 & 0.160412 & 0.618302 & $0.115^{*}$ \\
\hline $\mathrm{H} 20$ & 0.457257 & 0.059102 & 0.563713 & $0.115^{*}$ \\
\hline $\mathrm{C} 21$ & $0.4236(5)$ & 0.1871 & 0.4858 & $0.0511(11)$ \\
\hline H17 & 0.310604 & 0.189950 & 0.490762 & $0.061 *$ \\
\hline H18 & 0.426010 & 0.137188 & 0.435721 & $0.061 *$ \\
\hline $\mathrm{S} 3$ & $0.82518(12)$ & $0.69438(9)$ & $0.34950(7)$ & $0.0466(3)$ \\
\hline S4 & $0.51549(12)$ & $0.59778(9)$ & $0.24947(7)$ & 0.0421 \\
\hline S5 & $0.45793(13)$ & $0.38249(9)$ & $0.38374(7)$ & 0.0438 \\
\hline S6 & $0.76624(13)$ & $0.48567(9)$ & $0.48358(8)$ & $0.0486(3)$ \\
\hline I1 & 1.000000 & 0.000000 & 0.500000 & $0.04237(11)$ \\
\hline $\mathrm{I} 2$ & $0.96057(4)$ & $0.18959(3)$ & 0.38707 (2) & 0.05908 (11) \\
\hline I3 & $0.02295(4)$ & $0.43954(3)$ & $0.25421(2)$ & $0.05695(10)$ \\
\hline $\mathrm{I} 4$ & 0.08720 & $0.63328(2)$ & $0.13886(2)$ & $0.04368(9)$ \\
\hline I5 & $0.15401(4)$ & 0.83474 & $0.02504(2)$ & $0.05716(11)$ \\
\hline
\end{tabular}

Atomic displacement parameters $\left(\AA^{2}\right)$

\begin{tabular}{lllllll}
\hline & $U^{11}$ & $U^{22}$ & $U^{33}$ & $U^{12}$ & $U^{13}$ & $U^{23}$ \\
\hline C1 & $0.035(2)$ & $0.035(2)$ & $0.037(2)$ & $0.0074(18)$ & $-0.0009(17)$ & $-0.0009(17)$ \\
C2 & $0.037(3)$ & $0.036(2)$ & $0.039(2)$ & $0.0082(19)$ & $0.0024(18)$ & $0.0057(18)$ \\
C3 & $0.044(3)$ & $0.032(2)$ & $0.039(2)$ & $0.0088(18)$ & $0.0067(18)$ & $0.0079(18)$ \\
C4 & $0.040(3)$ & $0.049(3)$ & $0.051(3)$ & $0.020(2)$ & $0.0036(19)$ & $0.016(2)$ \\
C5 & $0.063(3)$ & $0.062(3)$ & $0.092(4)$ & $0.026(3)$ & $0.014(3)$ & $0.037(3)$ \\
C6 & $0.060(3)$ & $0.058(3)$ & $0.073(3)$ & $0.012(3)$ & $0.005(2)$ & $0.029(3)$ \\
C7 & $0.038(3)$ & $0.052(3)$ & $0.047(2)$ & $0.006(2)$ & $0.0036(19)$ & $0.012(2)$ \\
S1 & $0.0330(6)$ & $0.0437(6)$ & $0.0507(6)$ & $0.0065(5)$ & $0.0018(5)$ & $0.0150(5)$ \\
S2 & $0.0352(6)$ & $0.0459(7)$ & $0.0568(7)$ & $0.0106(5)$ & $0.0021(5)$ & $0.0178(5)$ \\
C8 & $0.029(2)$ & $0.040(2)$ & $0.042(2)$ & $0.0100(18)$ & $0.0037(17)$ & $0.0039(18)$ \\
C9 & $0.032(2)$ & $0.038(2)$ & $0.043(2)$ & $0.0073(18)$ & $0.0011(18)$ & $0.0026(19)$ \\
C10 & $0.029(2)$ & $0.035(2)$ & $0.044(2)$ & $0.0071(18)$ & $0.0069(18)$ & $0.0050(18)$ \\
C11 & $0.038(2)$ & $0.039(2)$ & $0.045(2)$ & $0.0023(19)$ & $0.0045(18)$ & $0.0049(19)$ \\
C12 & $0.059(3)$ & $0.047(3)$ & $0.068(3)$ & $0.008(2)$ & $0.003(2)$ & $0.015(2)$ \\
C13 & $0.068(3)$ & $0.054(3)$ & $0.052(3)$ & $0.006(3)$ & $-0.004(2)$ & $0.015(2)$ \\
C14 & $0.047(3)$ & $0.050(3)$ & $0.038(2)$ & $0.011(2)$ & $-0.0065(19)$ & $0.005(2)$ \\
C15 & $0.038(2)$ & $0.033(2)$ & $0.034(2)$ & $0.0066(18)$ & $0.0073(17)$ & $0.0006(17)$ \\
C16 & $0.039(2)$ & $0.038(2)$ & $0.043(2)$ & $0.0081(19)$ & $0.0017(19)$ & $0.0055(19)$
\end{tabular}


supporting information

\begin{tabular}{lllllll} 
C17 & $0.036(2)$ & $0.043(2)$ & $0.046(2)$ & $0.0126(19)$ & $0.0064(19)$ & $0.0052(19)$ \\
C18 & $0.038(2)$ & $0.054(3)$ & $0.055(3)$ & $0.013(2)$ & $-0.004(2)$ & $0.011(2)$ \\
C19 & $0.073(4)$ & $0.077(4)$ & $0.106(5)$ & $0.017(3)$ & $-0.010(3)$ & $0.043(3)$ \\
C20 & $0.079(4)$ & $0.073(4)$ & $0.115(5)$ & $-0.007(3)$ & $-0.031(3)$ & $0.050(3)$ \\
C21 & $0.055(3)$ & $0.040(3)$ & $0.051(3)$ & $0.001(2)$ & $0.000(2)$ & $0.010(2)$ \\
S3 & $0.0322(6)$ & $0.0483(7)$ & $0.0548(7)$ & $0.0036(5)$ & $-0.0046(5)$ & $0.0145(5)$ \\
S4 & $0.0373(6)$ & $0.0416(6)$ & $0.0420(6)$ & $0.0005(5)$ & $-0.0019(5)$ & $0.0044(5)$ \\
S5 & $0.0422(6)$ & $0.0401(6)$ & $0.0437(6)$ & $0.0025(5)$ & $-0.0064(5)$ & $0.0061(5)$ \\
S6 & $0.0328(6)$ & $0.0491(7)$ & $0.0582(7)$ & $0.0012(5)$ & $-0.0045(5)$ & $0.0139(5)$ \\
I1 & $0.0429(2)$ & $0.0382(2)$ & $0.0419(2)$ & $0.00195(17)$ & $0.00331(17)$ & $0.00827(17)$ \\
I2 & $0.0742(2)$ & $0.0530(2)$ & $0.05357(19)$ & $0.02108(16)$ & $0.00849(15)$ & $0.02068(15)$ \\
I3 & $0.0598(2)$ & $0.04395(18)$ & $0.0629(2)$ & $0.00554(15)$ & $0.00173(15)$ & $0.01986(15)$ \\
I4 & $0.04059(18)$ & $0.04315(17)$ & $0.04686(17)$ & $0.00971(13)$ & $0.00192(12)$ & $0.01106(12)$ \\
I5 & $0.0543(2)$ & $0.0586(2)$ & $0.0610(2)$ & $0.01688(15)$ & $0.00964(15)$ & $0.02880(15)$ \\
\hline
\end{tabular}

Geometric parameters $\left(\AA,{ }^{\circ}\right)$

\begin{tabular}{|c|c|c|c|}
\hline $\mathrm{C} 1-\mathrm{C} 1^{\mathrm{i}}$ & $1.405(7)$ & $\mathrm{C} 12-\mathrm{C} 13$ & $1.498(6)$ \\
\hline $\mathrm{C} 1-\mathrm{S} 2$ & $1.715(4)$ & $\mathrm{C} 12-\mathrm{H} 13$ & 0.9700 \\
\hline $\mathrm{C} 1-\mathrm{S} 1$ & $1.719(3)$ & $\mathrm{C} 12-\mathrm{H} 14$ & 0.9700 \\
\hline $\mathrm{C} 2-\mathrm{C} 3$ & $1.346(5)$ & $\mathrm{C} 13-\mathrm{C} 14$ & $1.525(6)$ \\
\hline $\mathrm{C} 2-\mathrm{C} 7$ & $1.501(5)$ & C13-H11 & 0.9700 \\
\hline $\mathrm{C} 2-\mathrm{S} 2$ & $1.731(4)$ & $\mathrm{C} 13-\mathrm{H} 12$ & 0.9700 \\
\hline $\mathrm{C} 3-\mathrm{C} 4$ & $1.508(5)$ & $\mathrm{C} 14-\mathrm{C} 15$ & $1.519(5)$ \\
\hline $\mathrm{C} 3-\mathrm{S} 1$ & $1.731(4)$ & $\mathrm{C} 14-\mathrm{H} 9$ & 0.9700 \\
\hline $\mathrm{C} 4-\mathrm{C} 5$ & $1.500(6)$ & $\mathrm{C} 14-\mathrm{H} 10$ & 0.9700 \\
\hline $\mathrm{C} 4-\mathrm{H} 7$ & 0.9700 & $\mathrm{C} 15-\mathrm{S} 4$ & $1.740(4)$ \\
\hline $\mathrm{C} 4-\mathrm{H} 8$ & 0.9700 & $\mathrm{C} 16-\mathrm{C} 17$ & $1.347(5)$ \\
\hline $\mathrm{C} 5-\mathrm{C} 6$ & $1.479(6)$ & $\mathrm{C} 16-\mathrm{C} 21$ & $1.498(5)$ \\
\hline $\mathrm{C} 5-\mathrm{H} 5$ & 0.9700 & $\mathrm{C} 16-\mathrm{S} 5$ & $1.737(4)$ \\
\hline $\mathrm{C} 5-\mathrm{H} 6$ & 0.9700 & $\mathrm{C} 17-\mathrm{C} 18$ & $1.496(5)$ \\
\hline $\mathrm{C} 6-\mathrm{C} 7$ & $1.510(5)$ & $\mathrm{C} 17-\mathrm{S} 6$ & $1.721(4)$ \\
\hline $\mathrm{C} 6-\mathrm{H} 3$ & 0.9700 & $\mathrm{C} 18-\mathrm{C} 19$ & $1.489(6)$ \\
\hline $\mathrm{C} 6-\mathrm{H} 4$ & 0.9700 & $\mathrm{C} 18-\mathrm{H} 23$ & 0.9700 \\
\hline $\mathrm{C} 7-\mathrm{H} 1$ & 0.9700 & $\mathrm{C} 18-\mathrm{H} 24$ & 0.9700 \\
\hline $\mathrm{C} 7-\mathrm{H} 2$ & 0.9700 & $\mathrm{C} 19-\mathrm{C} 20$ & $1.413(7)$ \\
\hline $\mathrm{C} 8-\mathrm{C} 9$ & $1.383(5)$ & $\mathrm{C} 19-\mathrm{H} 21$ & 0.9700 \\
\hline $\mathrm{C} 8-\mathrm{S} 3$ & $1.711(4)$ & $\mathrm{C} 19-\mathrm{H} 22$ & 0.9700 \\
\hline $\mathrm{C} 8-\mathrm{S} 4$ & $1.720(4)$ & $\mathrm{C} 20-\mathrm{C} 21$ & $1.496(5)$ \\
\hline C9-S6 & $1.724(4)$ & $\mathrm{C} 20-\mathrm{H} 19$ & 0.9700 \\
\hline C9-S5 & $1.727(4)$ & $\mathrm{C} 20-\mathrm{H} 20$ & 0.9700 \\
\hline $\mathrm{C} 10-\mathrm{C} 15$ & $1.322(5)$ & $\mathrm{C} 21-\mathrm{H} 17$ & 0.9700 \\
\hline $\mathrm{C} 10-\mathrm{C} 11$ & $1.496(5)$ & $\mathrm{C} 21-\mathrm{H} 18$ & 0.9700 \\
\hline $\mathrm{C} 10-\mathrm{S} 3$ & $1.736(4)$ & $\mathrm{I} 1-\mathrm{I} 2$ & $2.9344(3)$ \\
\hline $\mathrm{C} 11-\mathrm{C} 12$ & $1.533(5)$ & $\mathrm{I} 2-\mathrm{I} 1^{\mathrm{ii}}$ & $2.9344(3)$ \\
\hline $\mathrm{C} 11-\mathrm{H} 15$ & 0.9700 & $\mathrm{I} 3-\mathrm{I} 4$ & $2.8954(4)$ \\
\hline $\mathrm{C} 11-\mathrm{H} 16$ & 0.9700 & $\mathrm{I} 4-\mathrm{I} 5$ & $2.9555(4)$ \\
\hline
\end{tabular}




\begin{tabular}{|c|c|c|c|}
\hline $\mathrm{C} 1-\mathrm{C} 1-\mathrm{S} 2$ & $122.6(4)$ & $\mathrm{C} 11-\mathrm{C} 12-\mathrm{H} 14$ & 109.2 \\
\hline $\mathrm{C} 1-\mathrm{C} 1-\mathrm{S} 1$ & $122.0(4)$ & $\mathrm{H} 13-\mathrm{C} 12-\mathrm{H} 14$ & 107.9 \\
\hline $\mathrm{S} 2-\mathrm{C} 1-\mathrm{S} 1$ & $115.4(2)$ & $\mathrm{C} 12-\mathrm{C} 13-\mathrm{C} 14$ & $112.6(4)$ \\
\hline $\mathrm{C} 3-\mathrm{C} 2-\mathrm{C} 7$ & $124.3(3)$ & $\mathrm{C} 12-\mathrm{C} 13-\mathrm{H} 11$ & 109.1 \\
\hline $\mathrm{C} 3-\mathrm{C} 2-\mathrm{S} 2$ & $116.5(3)$ & $\mathrm{C} 14-\mathrm{C} 13-\mathrm{H} 11$ & 109.1 \\
\hline $\mathrm{C} 7-\mathrm{C} 2-\mathrm{S} 2$ & $119.2(3)$ & $\mathrm{C} 12-\mathrm{C} 13-\mathrm{H} 12$ & 109.1 \\
\hline $\mathrm{C} 2-\mathrm{C} 3-\mathrm{C} 4$ & $123.2(4)$ & $\mathrm{C} 14-\mathrm{C} 13-\mathrm{H} 12$ & 109.1 \\
\hline $\mathrm{C} 2-\mathrm{C} 3-\mathrm{S} 1$ & $117.0(3)$ & $\mathrm{H} 11-\mathrm{C} 13-\mathrm{H} 12$ & 107.8 \\
\hline $\mathrm{C} 4-\mathrm{C} 3-\mathrm{S} 1$ & $119.8(3)$ & $\mathrm{C} 15-\mathrm{C} 14-\mathrm{C} 13$ & $109.7(3)$ \\
\hline $\mathrm{C} 5-\mathrm{C} 4-\mathrm{C} 3$ & $110.8(3)$ & $\mathrm{C} 15-\mathrm{C} 14-\mathrm{H} 9$ & 109.7 \\
\hline $\mathrm{C} 5-\mathrm{C} 4-\mathrm{H} 7$ & 109.5 & $\mathrm{C} 13-\mathrm{C} 14-\mathrm{H} 9$ & 109.7 \\
\hline $\mathrm{C} 3-\mathrm{C} 4-\mathrm{H} 7$ & 109.5 & $\mathrm{C} 15-\mathrm{C} 14-\mathrm{H} 10$ & 109.7 \\
\hline $\mathrm{C} 5-\mathrm{C} 4-\mathrm{H} 8$ & 109.5 & $\mathrm{C} 13-\mathrm{C} 14-\mathrm{H} 10$ & 109.7 \\
\hline $\mathrm{C} 3-\mathrm{C} 4-\mathrm{H} 8$ & 109.5 & $\mathrm{H} 9-\mathrm{C} 14-\mathrm{H} 10$ & 108.2 \\
\hline $\mathrm{H} 7-\mathrm{C} 4-\mathrm{H} 8$ & 108.1 & $\mathrm{C} 10-\mathrm{C} 15-\mathrm{C} 14$ & $123.3(4)$ \\
\hline $\mathrm{C} 6-\mathrm{C} 5-\mathrm{C} 4$ & $115.6(4)$ & $\mathrm{C} 10-\mathrm{C} 15-\mathrm{S} 4$ & $117.8(3)$ \\
\hline $\mathrm{C} 6-\mathrm{C} 5-\mathrm{H} 5$ & 108.4 & $\mathrm{C} 14-\mathrm{C} 15-\mathrm{S} 4$ & $118.8(3)$ \\
\hline $\mathrm{C} 4-\mathrm{C} 5-\mathrm{H} 5$ & 108.4 & $\mathrm{C} 17-\mathrm{C} 16-\mathrm{C} 21$ & $124.0(4)$ \\
\hline $\mathrm{C} 6-\mathrm{C} 5-\mathrm{H} 6$ & 108.4 & $\mathrm{C} 17-\mathrm{C} 16-\mathrm{S} 5$ & $116.4(3)$ \\
\hline $\mathrm{C} 4-\mathrm{C} 5-\mathrm{H} 6$ & 108.4 & $\mathrm{C} 21-\mathrm{C} 16-\mathrm{S} 5$ & $119.6(3)$ \\
\hline $\mathrm{H} 5-\mathrm{C} 5-\mathrm{H} 6$ & 107.4 & $\mathrm{C} 16-\mathrm{C} 17-\mathrm{C} 18$ & $123.2(4)$ \\
\hline $\mathrm{C} 5-\mathrm{C} 6-\mathrm{C} 7$ & $114.2(4)$ & $\mathrm{C} 16-\mathrm{C} 17-\mathrm{S} 6$ & $116.9(3)$ \\
\hline $\mathrm{C} 5-\mathrm{C} 6-\mathrm{H} 3$ & 108.7 & $\mathrm{C} 18-\mathrm{C} 17-\mathrm{S} 6$ & $119.9(3)$ \\
\hline $\mathrm{C} 7-\mathrm{C} 6-\mathrm{H} 3$ & 108.7 & $\mathrm{C} 19-\mathrm{C} 18-\mathrm{C} 17$ & $112.5(4)$ \\
\hline $\mathrm{C} 5-\mathrm{C} 6-\mathrm{H} 4$ & 108.7 & $\mathrm{C} 19-\mathrm{C} 18-\mathrm{H} 23$ & 109.1 \\
\hline $\mathrm{C} 7-\mathrm{C} 6-\mathrm{H} 4$ & 108.7 & $\mathrm{C} 17-\mathrm{C} 18-\mathrm{H} 23$ & 109.1 \\
\hline $\mathrm{H} 3-\mathrm{C} 6-\mathrm{H} 4$ & 107.6 & $\mathrm{C} 19-\mathrm{C} 18-\mathrm{H} 24$ & 109.1 \\
\hline $\mathrm{C} 2-\mathrm{C} 7-\mathrm{C} 6$ & $111.6(3)$ & $\mathrm{C} 17-\mathrm{C} 18-\mathrm{H} 24$ & 109.1 \\
\hline $\mathrm{C} 2-\mathrm{C} 7-\mathrm{H} 1$ & 109.3 & $\mathrm{H} 23-\mathrm{C} 18-\mathrm{H} 24$ & 107.8 \\
\hline $\mathrm{C} 6-\mathrm{C} 7-\mathrm{H} 1$ & 109.3 & $\mathrm{C} 20-\mathrm{C} 19-\mathrm{C} 18$ & $118.2(4)$ \\
\hline $\mathrm{C} 2-\mathrm{C} 7-\mathrm{H} 2$ & 109.3 & $\mathrm{C} 20-\mathrm{C} 19-\mathrm{H} 21$ & 107.8 \\
\hline $\mathrm{C} 6-\mathrm{C} 7-\mathrm{H} 2$ & 109.3 & $\mathrm{C} 18-\mathrm{C} 19-\mathrm{H} 21$ & 107.8 \\
\hline $\mathrm{H} 1-\mathrm{C} 7-\mathrm{H} 2$ & 108.0 & $\mathrm{C} 20-\mathrm{C} 19-\mathrm{H} 22$ & 107.8 \\
\hline $\mathrm{C} 1-\mathrm{S} 1-\mathrm{C} 3$ & $95.36(18)$ & $\mathrm{C} 18-\mathrm{C} 19-\mathrm{H} 22$ & 107.8 \\
\hline $\mathrm{C} 1-\mathrm{S} 2-\mathrm{C} 2$ & $95.70(17)$ & $\mathrm{H} 21-\mathrm{C} 19-\mathrm{H} 22$ & 107.1 \\
\hline $\mathrm{C} 9-\mathrm{C} 8-\mathrm{S} 3$ & $121.7(3)$ & $\mathrm{C} 19-\mathrm{C} 20-\mathrm{C} 21$ & $119.5(5)$ \\
\hline $\mathrm{C} 9-\mathrm{C} 8-\mathrm{S} 4$ & $123.4(3)$ & $\mathrm{C} 19-\mathrm{C} 20-\mathrm{H} 19$ & 107.4 \\
\hline $\mathrm{S} 3-\mathrm{C} 8-\mathrm{S} 4$ & $115.0(2)$ & $\mathrm{C} 21-\mathrm{C} 20-\mathrm{H} 19$ & 107.4 \\
\hline $\mathrm{C} 8-\mathrm{C} 9-\mathrm{S} 6$ & $122.6(3)$ & $\mathrm{C} 19-\mathrm{C} 20-\mathrm{H} 20$ & 107.4 \\
\hline $\mathrm{C} 8-\mathrm{C} 9-\mathrm{S} 5$ & $123.1(3)$ & $\mathrm{C} 21-\mathrm{C} 20-\mathrm{H} 20$ & 107.4 \\
\hline S6-C9-S5 & $114.3(2)$ & $\mathrm{H} 19-\mathrm{C} 20-\mathrm{H} 20$ & 107.0 \\
\hline $\mathrm{C} 15-\mathrm{C} 10-\mathrm{C} 11$ & $125.5(3)$ & $\mathrm{C} 20-\mathrm{C} 21-\mathrm{C} 16$ & $111.1(4)$ \\
\hline $\mathrm{C} 15-\mathrm{C} 10-\mathrm{S} 3$ & $115.9(3)$ & $\mathrm{C} 20-\mathrm{C} 21-\mathrm{H} 17$ & 109.4 \\
\hline $\mathrm{C} 11-\mathrm{C} 10-\mathrm{S} 3$ & $118.5(3)$ & $\mathrm{C} 16-\mathrm{C} 21-\mathrm{H} 17$ & 109.4 \\
\hline $\mathrm{C} 10-\mathrm{C} 11-\mathrm{C} 12$ & $109.7(3)$ & $\mathrm{C} 20-\mathrm{C} 21-\mathrm{H} 18$ & 109.4 \\
\hline $\mathrm{C} 10-\mathrm{C} 11-\mathrm{H} 15$ & 109.7 & $\mathrm{C} 16-\mathrm{C} 21-\mathrm{H} 18$ & 109.4 \\
\hline $\mathrm{C} 12-\mathrm{C} 11-\mathrm{H} 15$ & 109.7 & $\mathrm{H} 17-\mathrm{C} 21-\mathrm{H} 18$ & 108.0 \\
\hline $\mathrm{C} 10-\mathrm{C} 11-\mathrm{H} 16$ & 109.7 & $\mathrm{C} 8-\mathrm{S} 3-\mathrm{C} 10$ & $96.23(17)$ \\
\hline
\end{tabular}




\begin{tabular}{|c|c|c|c|}
\hline $\mathrm{C} 12-\mathrm{C} 11-\mathrm{H} 16$ & 109.7 & $\mathrm{C} 8-\mathrm{S} 4-\mathrm{C} 15$ & $95.03(18)$ \\
\hline $\mathrm{H} 15-\mathrm{C} 11-\mathrm{H} 16$ & 108.2 & $\mathrm{C} 9-\mathrm{S} 5-\mathrm{C} 16$ & $95.82(18)$ \\
\hline $\mathrm{C} 13-\mathrm{C} 12-\mathrm{C} 11$ & $112.2(4)$ & $\mathrm{C} 17-\mathrm{S} 6-\mathrm{C} 9$ & $96.25(19)$ \\
\hline $\mathrm{C} 13-\mathrm{C} 12-\mathrm{H} 13$ & 109.2 & $\mathrm{I} 2-\mathrm{I} 1-\mathrm{I} 2^{\mathrm{ii}}$ & 180.0 \\
\hline $\mathrm{C} 11-\mathrm{C} 12-\mathrm{H} 13$ & 109.2 & $\mathrm{I} 3-\mathrm{I} 4-\mathrm{I} 5$ & $178.593(13)$ \\
\hline $\mathrm{C} 13-\mathrm{C} 12-\mathrm{H} 14$ & 109.2 & & \\
\hline $\mathrm{C} 7-\mathrm{C} 2-\mathrm{C} 3-\mathrm{C} 4$ & $-1.8(6)$ & $\mathrm{S} 3-\mathrm{C} 10-\mathrm{C} 15-\mathrm{S} 4$ & $-0.9(4)$ \\
\hline $\mathrm{S} 2-\mathrm{C} 2-\mathrm{C} 3-\mathrm{C} 4$ & $-179.2(3)$ & $\mathrm{C} 13-\mathrm{C} 14-\mathrm{C} 15-\mathrm{C} 10$ & $17.4(5)$ \\
\hline $\mathrm{C} 7-\mathrm{C} 2-\mathrm{C} 3-\mathrm{S} 1$ & $177.3(3)$ & $\mathrm{C} 13-\mathrm{C} 14-\mathrm{C} 15-\mathrm{S} 4$ & $-166.5(3)$ \\
\hline $\mathrm{S} 2-\mathrm{C} 2-\mathrm{C} 3-\mathrm{S} 1$ & $-0.1(4)$ & $\mathrm{C} 21-\mathrm{C} 16-\mathrm{C} 17-\mathrm{C} 18$ & $-0.7(7)$ \\
\hline $\mathrm{C} 2-\mathrm{C} 3-\mathrm{C} 4-\mathrm{C} 5$ & $15.3(6)$ & $\mathrm{S} 5-\mathrm{C} 16-\mathrm{C} 17-\mathrm{C} 18$ & $179.9(3)$ \\
\hline $\mathrm{S} 1-\mathrm{C} 3-\mathrm{C} 4-\mathrm{C} 5$ & $-163.8(3)$ & $\mathrm{C} 21-\mathrm{C} 16-\mathrm{C} 17-\mathrm{S} 6$ & $179.1(3)$ \\
\hline $\mathrm{C} 3-\mathrm{C} 4-\mathrm{C} 5-\mathrm{C} 6$ & $-41.0(6)$ & $\mathrm{S} 5-\mathrm{C} 16-\mathrm{C} 17-\mathrm{S} 6$ & $-0.2(4)$ \\
\hline $\mathrm{C} 4-\mathrm{C} 5-\mathrm{C} 6-\mathrm{C} 7$ & $54.4(6)$ & $\mathrm{C} 16-\mathrm{C} 17-\mathrm{C} 18-\mathrm{C} 19$ & $9.7(6)$ \\
\hline $\mathrm{C} 3-\mathrm{C} 2-\mathrm{C} 7-\mathrm{C} 6$ & $12.3(6)$ & $\mathrm{S} 6-\mathrm{C} 17-\mathrm{C} 18-\mathrm{C} 19$ & $-170.2(3)$ \\
\hline $\mathrm{S} 2-\mathrm{C} 2-\mathrm{C} 7-\mathrm{C} 6$ & $-170.3(3)$ & $\mathrm{C} 17-\mathrm{C} 18-\mathrm{C} 19-\mathrm{C} 20$ & $-29.8(7)$ \\
\hline $\mathrm{C} 5-\mathrm{C} 6-\mathrm{C} 7-\mathrm{C} 2$ & $-37.3(6)$ & $\mathrm{C} 18-\mathrm{C} 19-\mathrm{C} 20-\mathrm{C} 21$ & $42.4(9)$ \\
\hline $\mathrm{C} 1-\mathrm{C} 1-\mathrm{S} 1-\mathrm{C} 3$ & $-178.2(4)$ & $\mathrm{C} 19-\mathrm{C} 20-\mathrm{C} 21-\mathrm{C} 16$ & $-30.3(8)$ \\
\hline $\mathrm{S} 2-\mathrm{C} 1-\mathrm{S} 1-\mathrm{C} 3$ & $1.7(3)$ & $\mathrm{C} 17-\mathrm{C} 16-\mathrm{C} 21-\mathrm{C} 20$ & $9.7(7)$ \\
\hline $\mathrm{C} 2-\mathrm{C} 3-\mathrm{S} 1-\mathrm{C} 1$ & $-1.0(3)$ & $\mathrm{S} 5-\mathrm{C} 16-\mathrm{C} 21-\mathrm{C} 20$ & $-170.9(3)$ \\
\hline $\mathrm{C} 4-\mathrm{C} 3-\mathrm{S} 1-\mathrm{C} 1$ & $178.1(3)$ & $\mathrm{C} 9-\mathrm{C} 8-\mathrm{S} 3-\mathrm{C} 10$ & $179.3(3)$ \\
\hline $\mathrm{C} 1-\mathrm{C} 1-\mathrm{S} 2-\mathrm{C} 2$ & $178.1(4)$ & $\mathrm{S} 4-\mathrm{C} 8-\mathrm{S} 3-\mathrm{C} 10$ & $-0.2(2)$ \\
\hline $\mathrm{S} 1-\mathrm{C} 1-\mathrm{S} 2-\mathrm{C} 2$ & $-1.8(3)$ & $\mathrm{C} 15-\mathrm{C} 10-\mathrm{S} 3-\mathrm{C} 8$ & $0.7(3)$ \\
\hline $\mathrm{C} 3-\mathrm{C} 2-\mathrm{S} 2-\mathrm{C} 1$ & $1.2(3)$ & $\mathrm{C} 11-\mathrm{C} 10-\mathrm{S} 3-\mathrm{C} 8$ & $179.7(3)$ \\
\hline $\mathrm{C} 7-\mathrm{C} 2-\mathrm{S} 2-\mathrm{C} 1$ & $-176.4(3)$ & $\mathrm{C} 9-\mathrm{C} 8-\mathrm{S} 4-\mathrm{C} 15$ & $-179.7(3)$ \\
\hline $\mathrm{S} 3-\mathrm{C} 8-\mathrm{C} 9-\mathrm{S} 6$ & $1.0(5)$ & $\mathrm{S} 3-\mathrm{C} 8-\mathrm{S} 4-\mathrm{C} 15$ & $-0.1(2)$ \\
\hline $\mathrm{S} 4-\mathrm{C} 8-\mathrm{C} 9-\mathrm{S} 6$ & $-179.5(2)$ & $\mathrm{C} 10-\mathrm{C} 15-\mathrm{S} 4-\mathrm{C} 8$ & $0.6(3)$ \\
\hline $\mathrm{S} 3-\mathrm{C} 8-\mathrm{C} 9-\mathrm{S} 5$ & $-178.3(2)$ & $\mathrm{C} 14-\mathrm{C} 15-\mathrm{S} 4-\mathrm{C} 8$ & $-175.7(3)$ \\
\hline $\mathrm{S} 4-\mathrm{C} 8-\mathrm{C} 9-\mathrm{S} 5$ & $1.2(5)$ & $\mathrm{C} 8-\mathrm{C} 9-\mathrm{S} 5-\mathrm{C} 16$ & $174.4(3)$ \\
\hline $\mathrm{C} 15-\mathrm{C} 10-\mathrm{C} 11-\mathrm{C} 12$ & $16.4(6)$ & $\mathrm{S} 6-\mathrm{C} 9-\mathrm{S} 5-\mathrm{C} 16$ & $-5.0(3)$ \\
\hline $\mathrm{S} 3-\mathrm{C} 10-\mathrm{C} 11-\mathrm{C} 12$ & $-162.5(3)$ & $\mathrm{C} 17-\mathrm{C} 16-\mathrm{S} 5-\mathrm{C} 9$ & $3.2(3)$ \\
\hline $\mathrm{C} 10-\mathrm{C} 11-\mathrm{C} 12-\mathrm{C} 13$ & $-43.9(5)$ & $\mathrm{C} 21-\mathrm{C} 16-\mathrm{S} 5-\mathrm{C} 9$ & $-176.2(3)$ \\
\hline $\mathrm{C} 11-\mathrm{C} 12-\mathrm{C} 13-\mathrm{C} 14$ & $61.3(5)$ & $\mathrm{C} 16-\mathrm{C} 17-\mathrm{S} 6-\mathrm{C} 9$ & $-2.8(4)$ \\
\hline $\mathrm{C} 12-\mathrm{C} 13-\mathrm{C} 14-\mathrm{C} 15$ & $-45.3(5)$ & $\mathrm{C} 18-\mathrm{C} 17-\mathrm{S} 6-\mathrm{C} 9$ & $177.0(3)$ \\
\hline $\mathrm{C} 11-\mathrm{C} 10-\mathrm{C} 15-\mathrm{C} 14$ & $-3.7(6)$ & $\mathrm{C} 8-\mathrm{C} 9-\mathrm{S} 6-\mathrm{C} 17$ & $-174.5(3)$ \\
\hline $\mathrm{S} 3-\mathrm{C} 10-\mathrm{C} 15-\mathrm{C} 14$ & $175.2(3)$ & $\mathrm{S} 5-\mathrm{C} 9-\mathrm{S} 6-\mathrm{C} 17$ & $4.9(3)$ \\
\hline $\mathrm{C} 11-\mathrm{C} 10-\mathrm{C} 15-\mathrm{S} 4$ & $-179.8(3)$ & & \\
\hline
\end{tabular}

Symmetry codes: (i) $-x+1,-y+1,-z$; (ii) $-x+2,-y,-z+1$.

Hydrogen-bond geometry $\left(A,{ }^{\circ}\right)$

\begin{tabular}{lllll}
\hline$D-\mathrm{H} \cdots A$ & $D-\mathrm{H}$ & $\mathrm{H} \cdots A$ & $D \cdots A$ & $D-\mathrm{H} \cdots A$ \\
\hline $\mathrm{C} 18-\mathrm{H} 23 \cdots \mathrm{S}{ }^{3 i i}$ & 0.97 & 2.80 & $3.669(4)$ & 150 \\
$\mathrm{C} 21-\mathrm{H} 17 \cdots \mathrm{I} 1^{\text {iv }}$ & 0.97 & 3.06 & $3.763(4)$ & 131 \\
\hline
\end{tabular}

Symmetry codes: (iii) $-x+2,-y+1,-z+1$; (iv) $x-1, y, z$. 